\title{
The Influence of Large-Scale Phenomena on La Paz Bay Hydrographic Variability
}

\author{
Cristóbal Guevara-Guillén*, Bernardo Shirasago-Germán, Edgar Leonardo Pérez-Lezama \\ Centro Interdisciplinario de Ciencias Marinas (CICIMAR-IPN), Colonia Playa Palo de Santa Rita, \\ La Paz, México \\ Email: ${ }^{*}$ gcristobalg@hotmail.com
}

Received 2 January 2015; accepted 25 January 2015; published 27 January 2015

Copyright (C) 2015 by authors and Scientific Research Publishing Inc.

This work is licensed under the Creative Commons Attribution International License (CC BY). http://creativecommons.org/licenses/by/4.0/

(c) (i) Open Access

\begin{abstract}
We analyzed the hydrographic variability of La Paz Bay, the largest coastal water body in the Gulf of California, and its relationship with Pacific large-scale phenomena, including the El NiñoSouthern Oscillation (ENSO), Pacific Decadal Oscillation (PDO), Pacific-North America pattern (PNA), and North Pacific pattern (NP). We used several indices related to these phenomena and the hydrographic variability data of La Paz Bay, consisting of the annual sea surface temperature patterns from satellite imagery from 2000 to 2010 and the mixed layer depths measured with in situ data from 1994 to 2009 . The results indicate the sea surface temperature fluctuated during the study period, with 2007 as the coldest year and 2009 as the warmest. Two periods were identified in the annual thermal cycle of the bay, one period of warmth from June to November, and one of cold from December to May. The sea surface temperature is primarily influenced by the ENSO. The mixed layer depth analysis showed its absence during August-September, while the deepest ones were in November-March. The unusual $100 \mathrm{~m}$ mixed layer depth noted during February 2002 and its absence in March 1996 and 2009 were related to uncommon atmospheric conditions in the annual patterns of the ENSO, PNA, and NP. The variability of the mixed layer depth is primarily related to the variability of the NP. We concluded that the hydrographic conditions of La Paz Bay are most influenced by the NP during the cold phase of its annual cycle, and by the ENSO during the warm phase.
\end{abstract}

\section{Keywords}

Pacific Large-Scale Phenomena, La Paz Bay, Gulf of California, Hydrography, Annual Patterns

\section{Introduction}

Many large-scale phenomena occur in the Pacific Ocean that act on varied time-scales, from the El Niño"Corresponding author.

How to cite this paper: Guevara-Guillén, C., Shirasago-Germán, B. and Pérez-Lezama, E.L. (2015) The Influence of LargeScale Phenomena on La Paz Bay Hydrographic Variability. Open Journal of Marine Science, 5, 146-157.

http://dx.doi.org/10.4236/ojms.2015.51012 
Southern Oscillation (ENSO) with month-year cycles to decadal-to-multidecadal frequency events such as the Pacific Decadal Oscillation (PDO). Their effects are detectable in global to local ecosystems, and their aggregate contributions establish climatic shifts that have shown fluctuations in the atmospheric and oceanic conditions such as sea temperature [1], wind fields associated with atmospheric pressure variations [2], ocean currents [3], coastal upwellings [4], and mixed layer depths [5]. Many of these climatic variations occur via atmosphericoceanic teleconnections [6], which extend from the troposphere to the ocean surface, including fluctuations in sea level pressure that are closely linked to changes in the surface winds, sea surface temperature, heat content, mixed layer, and thermocline depth. Climate variability due to large-scale influences in the North Pacific receives considerable attention due to its impact on tropical and extra-tropical climate [7] and the weather over North America [8].

The ENSO, perhaps the most studied large-scale phenomenon, is comprised of two phases. The warm El Niño phase, which has been studied extensively in the Pacific Ocean [6] [9], is characterized by the weakening of trade winds, warming of the sea surface layer in the tropical-subtropical eastern Pacific, a switch from low to high atmospheric pressure near Darwin, Australia, and the opposite effect near the Tahiti Islands, which is termed the Southern Oscillation. The La Niña cold phase of the ENSO is much less studied in the Pacific. It is characterized by an intensification of the trade winds, the cooling of the sea surface layer in the tropical-subtropical Eastern Pacific, very low atmospheric pressure near Darwin, Australia, and very high pressure near the Tahiti Islands [10] [11].

The Pacific Decadal Oscillation (PDO), another large-scale phenomenon, is a pattern of ocean variability over the entire Pacific that is similar to the ENSO in some respects, but with a much longer cycle [12] [13]. It is also defined by two phases; the positive phase in the North Pacific occurs when the sea surface temperature anomalies are cold in the central North Pacific and warm along the Pacific coast and when the sea level pressure is below average in the North Pacific [14], while the converse occurs during the negative phase. Both phases are calculated by the standardized difference between sea surface temperatures in the north-central Pacific and Gulf of Alaska. The phases of the PDO may be important in enhancing or dampening the ENSO impacts [15].

The Pacific/North American (PNA) pattern is one of the most prominent modes of low-frequency variability in the Northern hemisphere extra-tropics, and it describes the variation of atmospheric circulation patterns over the Pacific Ocean and North America that involve changes in the atmospheric pressure between the Aleutian Low and the high pressure over the Rocky Mountains [16] [17]. The PNA has the most impact on climate variables during the winter [18] [19]. As with the first two phenomena, the PNA also presents two phases, with the positive phase usually related to El Niño and the negative phase to La Niña. However, there is also a weak connection between the PNA and the ENSO [20]-[22]. During the positive phase of the PNA, the Aleutian Low in the intermountain region of North America shows anomalous low pressures, while the high pressure over the Rocky Mountains and Northeast Pacific Coast strengthens, increasing the pressure gradient between the two centers of circulation, in addition to increasing the wind speed, which steers more storms into the Northwest Pacific. The negative phase of the PNA is essentially the reverse pattern of the positive phase [16].

The North Pacific pattern is quite similar to the PNA, but the variables involved in this atmospheric process are considered differently. For the PNA, [16] considered four centers of action in the mid-tropospheric height field, one each of one sign near Hawaii and along the west coast of North America, and one each of the opposite sign over the north Pacific and southeastern United States. According to [23], these four centers of action and their resulting index have proven to be useful, but they also consider it inappropriate to weight the four centers of the PNA similarly, as the North Pacific has by far the most prominent height field. They proposed the North Pacific pattern and its index as a much more robust, but simpler measure of the atmospheric processes in North America.

The Pacific Ocean exerts a strong influence over the oceanographic conditions of the Gulf of California, the sea that shelters La Paz Bay, due its connection to the eastern tropical Pacific [24]. The dynamic forcing from the Pacific Ocean over the gulf is one of the most important oceanographic features, because it integrates relevant phenomena such as salt and heat global balances, thermohaline circulation, and barotropic ocean circulation [25] [26].

Studies have demonstrated the effects of these large-scale phenomena on the Gulf of California region, and satellite analysis has shown the influence of the ENSO over the sea surface temperature variability. Based on the satellite records of the sea surface temperature anomalies, [27] [28] showed that during El Niño, the temperature in the gulf registered up to $3^{\circ} \mathrm{C}$ above normal, while during La Niña, it was up to $3^{\circ} \mathrm{C}$ below normal. 
Similarly, studies on the PDO have shown its influence on pressure, wind, temperature, and the precipitation patterns of the North Pacific [12] [29] [30]. Its temporal modulations are linked to several important biological and ecosystem variables in the ocean [31] [32]. Nevertheless, other parameters such as the decadal fluctuations in salinity, nutrients, and chlorophyll a in the eastern North Pacific are often poorly correlated with the PDO [33].

The relationship between the sea surface temperature over the Pacific Ocean and the PNA has also been studied by [34]-[36], who determined that the PNA pattern is positively correlated with the sea surface temperature anomalies over the tropical Pacific [34] [37] and negatively correlated with those anomalies over the North Pacific [38]. The link between the PNA and the tropical sea surface temperature anomalies is mostly attributed to the ENSO phenomenon. During an El Niño event, atmosphere-ocean interactions generate a seesaw pattern with opposing anomalies of the surface pressure in the eastern and western tropical Pacific [36].

On the other hand, a dependence of the western North Pacific $\left(28^{\circ}-31.5^{\circ} \mathrm{N}, 133^{\circ}-137^{\circ} \mathrm{E}\right)$ mixed layer depth on decadal and inter-decadal time-scales (1950-1997) and large-scale, low-frequency North Pacific climatic variability has been reported [39]. These authors found an inverse relationship between the mixed layer depth and the NP index in 1962-1965 and 1973-1997 and suggested that its close linkage is caused by the alternating wind stress fields. Studies of the eastern North Pacific mixed layer depth variability (Baja California eastern boundary currents) are extremely important for evaluating the effects of local and basin-scale changes in the ocean surface. In particular, the low-frequency mixed layer depth changes in the eastern North Pacific are related to large-scale atmospheric forcing on the Pacific Ocean [40].

Some large-scale phenomena effects on La Paz Bay have already been reported, primarily related to El Niño events, such as the sinking of the thermocline and isotherms and a warming of the entire water column $\left(>4^{\circ} \mathrm{C}\right)$ during the summer-autumn of 1997 . Nevertheless, some inconsistencies trying to relate other physical events with the ENSO cycles are present, such as the unusual $100 \mathrm{~m}$ mixed layer depth during the winter of 2002 in a non-ENSO period [41], and the absence of a mixed layer during the La Niña period in the winter of 1996 and 2009 [42] [43], a period when theoretically it should have been dominated by strong and persistent winds.

It is important to mention that La Paz Bay is a coastal water body of economic interest due to its tourism industry and fishing activities that are maintained by the high biological productivity of the bay, as well as by its contiguity to La Paz City, the capital of Baja California Sur. Thus, a better understanding of the processes that affect that productivity such as the North Pacific large-scale phenomena is required, as most studies have only focused on the ENSO influence, particularly the temperature variations. Consequently, we analyzed the variability of two hydrographic characteristics, sea surface temperature from 2000 to 2010 and mixed layer depth from 1994 to 2009, to determine their relationships with the climatic phenomena of the North Pacific.

\section{Materials and Methods}

\subsection{Study Area}

La Paz Bay is located between $24.1^{\circ}-24.8^{\circ} \mathrm{N}$ and $110.2^{\circ}-110.8^{\circ} \mathrm{W}$ (Figure 1). It is the largest bay in the Gulf of California (80 km long and $35 \mathrm{~km}$ wide) and consists of two basins: one in the north with a depth of up to $450 \mathrm{~m}$



Figure 1. La Paz Bay location and sampling stations. 
and another in the south with an average depth of $40 \mathrm{~m}$. It is connected to the Gulf of California by two passages: the North Mouth (350 m depth) and the San Lorenzo Channel (10 m depth) [44]. The water column structure of the bay is characterized by a well-defined mixed layer during the winter and spring and a surface-stratified layer during the summer and fall [45] [46]. The winds over the bay are northwesterly from November to March (up to $10 \mathrm{~m} / \mathrm{s}$ ), with a moderate intensity during most of the year and southeasterly with less intensity $(\sim 2 \mathrm{~m} / \mathrm{s})$ during the summer with frequent calms [42] [47]. The bay presents an arid climate (BWh type) with scarce and irregular precipitation. The evaporation $(215 \mathrm{~mm} / \mathrm{yr})$ exceeds the precipitation $(180 \mathrm{~mm} / \mathrm{yr})$, and the tides are predominantly mixed semidiurnal [48].

\subsection{Hydrographic Analysis}

\subsubsection{Sea Surface Temperature}

To detect the sea surface annual variability of La Paz Bay, the temperature data was obtained from 130 NOAAAVHRR images (2000-2010) of monthly averaged sea surface temperatures with a spatial resolution of $1.1 \mathrm{~km}$ at nadir, provided by the Scripps Institution of Oceanography in Hierarchical Data Format (HDF). These were visualized and processed with Windows Image Manager [49] to obtain the annual averages for comparison purposes to detect the variations over the study period with respect to the monthly mean data, thereby identifying the warmest and coldest years, the mean annual cycle, and the annual cycles of the thermally extreme years (i.e., 2007, 2009). Temperature anomalies were also obtained from the satellite data and compared with the variability of the North Pacific climate indices.

\subsubsection{Mixed Layer Depth}

The mixed layer depth was measured and averaged from in situ temperature data collected from 29 stations with a Sea-Bird SBE 19 plus during sixteen oceanographic surveys performed in May, July, and October of 2001, February 2002, October 2004, February 2005, August 2006, March 2007, February, May and November of 2008, and March, June, September, and December of 2009 (Figure 1). Mixed layer depths from 1994 to 1999 were obtained from data reported by [41] [42].

\subsection{Climate Indices}

To obtain a more precise scheme of the environmental fluctuations and their possible consequences for the Gulf of California and La Paz Bay region, the monthly values of the following climate indices were used: 1) Oceanic Niño Index (ONI), defined as the three-month running mean of sea surface temperature anomalies in the Niño 3.4 region $\left(5^{\circ} \mathrm{N}-5^{\circ} \mathrm{S}, 120^{\circ}-170^{\circ} \mathrm{W}\right)$; 2) Multivariate ENSO Index (MEI), based on six variables over the tropical Pacific: sea level pressure, the zonal and meridional components of the surface wind, sea surface temperature, surface air temperature, and the total cloudiness fraction of the sky; 3) Bivariate ENSO Time series (BEST), calculated by combining a standardized SOI and a standardized Niño 3.4 sea surface temperature time-series; 4) Southern Oscillation Index (SOI), based on the observed sea level pressure differences between Tahiti and Darwin, Australia; 5) Northern Oscillation Index (NOI), based on the difference in sea level pressure anomalies at the North Pacific High $\left(35^{\circ} \mathrm{N}, 135^{\circ} \mathrm{W}\right)$ and near Darwin Australia; 6) Pacific Decadal Oscillation (PDO), the first principal component of the North Pacific sea surface temperature anomalies field $\left(20^{\circ} \mathrm{N}-70^{\circ} \mathrm{N}\right)$ with subtracted global mean; 7) the Pacific North American index (PNA), consisting of anomalies in the geopotential height fields (typically at 700 or $500 \mathrm{mb}$ ) observed over western and eastern North America; and 8) the North Pacific pattern index (NP), the area-weighted sea level pressure over the region $30^{\circ} \mathrm{N}-65^{\circ} \mathrm{N}, 160^{\circ} \mathrm{E}-140^{\circ} \mathrm{W}$. All indices were obtained from the National Oceanic \& Atmospheric Administration data base [50].

\subsection{Statistical Analysis}

The climate index data were averaged annually to find trends and compare them with the interannual sea surface temperature anomalies. The monthly sea surface temperature anomalies and the eight Pacific climate indices were compared, while the mixed layer depths were only compared with the index values for each of the corresponding survey dates and with the indices representing atmospheric pressure fluctuations that could cause wind pattern changes (i.e., NP, PNA, NOI, and SOI) and thus influence the mixed layer depth. Spearman correlation analyses were conducted for all comparisons. 
To identify the causes of the unusual mixed layer depths (i.e., February 2002 and March 2009), we plotted the annual patterns for the monthly data of the NP, PNA, NOI, and SOI indices to describe the differences that could cause these anomalous depths.

\section{Results}

The sea surface temperature annual averages (2000-2010) showed that 2003, 2004, 2006, 2009, and 2010 were the warm years (Figure 2), and 2000, 2001, 2002, 2005, 2007, and 2008 were the cold years, with abrupt changes from 2006 to 2007 and from 2008 to 2009.

Two periods were clearly distinguished in the annual cycle of the sea surface temperature in La Paz Bay (Figure 3), a cold period with an average temperature range of $20.5^{\circ} \mathrm{C}-26.0^{\circ} \mathrm{C}$ during December-May and a warm period of $26.0^{\circ} \mathrm{C}-31.0^{\circ} \mathrm{C}$ during June-November. Figure 3 also shows the variations in 2007 and 2009, the coldest and warmest years of the study period. From January to April, the temperatures of both years were slightly above the mean, but from May to December the temperatures were above the mean in 2009 and below it in 2007, with the exception of October-November, when all of the temperatures were quite similar.

Table 1 shows the annual variability of the two sea surface temperature anomalies (SSTa) and the climate indices involved in this study, revealing that the SSTa variability is similar to that of the ONI and MEI climate indices in relation to the ENSO events. The Spearman correlation analysis corroborates this similarity, showing high correlations among the SSTa and the ONI and MEI indices.

Given the ONI had the highest correlation with the SSTa, we plotted both annual variabilities (Figure 4) and found a high similarity between them, reaffirming that the sea surface temperature changes occurring in the El Niño 3.4 zone have an influence on the changes in this parameter in La Paz Bay. However, a high discrepancy was observed in 2000 and 2002 when the sea surface temperature anomaly in the bay was negative and the ONI was positive and above 0.5 .



Figure 2. Annual average sea surface temperature of La Paz Bay from2000 to 2010.



Figure 3. The annual cycle of sea surface temperature variability in La Paz Bay (solid line) and the monthly variability in 2007, the coldest (short-dashed line) year, and 2009, the warmest (large-dashed line). 




Figure 4. The 11-year time series of sea surface temperature anomalies of La Paz Bay from satellite images (solid line) and the Oceanic Niño Index (dashed line) (shadow areas denote high discrepancies).

Table 1. The annual series of sea surface temperature anomalies (SSTa) in La Paz Bay and the eight North Pacific climate indices involved in this study from 2000 to 2010 with their Spearman correlations. $\mathrm{P}<0.005$; bolded numbers have a significant correlation.

\begin{tabular}{cccccccccc}
\hline Year & SSTa $\left({ }^{\circ} \mathrm{C}\right)$ & ONI & MEI & BEST & SOI & NOI & PDO & PNA & NP \\
\hline 2000 & -0.17 & -0.82 & -0.48 & -0.82 & 1.42 & 0.41 & -0.46 & -0.18 & 1011.60 \\
2001 & -0.24 & -0.28 & -0.16 & -0.10 & 0.40 & 0.32 & -0.56 & 0.03 & 1012.17 \\
2002 & -0.08 & 0.72 & 0.63 & 0.91 & -0.64 & -0.69 & 0.22 & -0.07 & 1012.42 \\
2003 & 0.28 & 0.34 & 0.45 & 0.45 & -0.15 & -0.99 & 0.97 & 0.00 & 1011.90 \\
2004 & 0.20 & 0.44 & 0.41 & 0.49 & -0.43 & 0.63 & 0.35 & -0.04 & 1011.82 \\
2005 & -0.20 & 0.08 & 0.32 & 0.40 & -0.31 & -0.23 & 0.38 & 0.53 & 1011.28 \\
2006 & 0.40 & 0.13 & 0.30 & 0.32 & 0.02 & 0.52 & 0.19 & -0.28 & 1014.06 \\
2007 & -0.49 & -0.45 & -0.34 & -0.28 & 0.43 & 2.83 & -0.20 & 0.57 & 1012.27 \\
2008 & -0.32 & -0.69 & -0.69 & -0.93 & 1.88 & 2.29 & -1.29 & -0.11 & 1013.66 \\
2009 & 0.44 & 0.37 & 0.39 & 0.36 & 0.28 & 0.88 & -0.61 & 0.04 & 1013.31 \\
2010 & 0.17 & -0.32 & -0.43 & -0.92 & 1.53 & -0.45 & -0.31 & 0.49 & 1012.66 \\
SSTa Spearman & & $\mathbf{0 . 6 4}$ & $\mathbf{0 . 6 1}$ & 0.54 & -0.48 & -0.25 & 0.26 & -0.31 & 0.22 \\
\hline
\end{tabular}

In the case of the mixed layer depth variability, the larger depths were measured during December, February, and March, corresponding to the cold period of the bay, and during October and November, the months when temperature decreases begin in the bay. Standing out, the largest mixed layer depth of $100 \mathrm{~m}$ was during February 2002, while the common depth during this period was $\sim 50 \mathrm{~m}$ (Table 2). This contrasts with the absence of the mixed layer during March of 1996 and 2009. Table 2 also shows the Spearman correlation analysis, which only found a statistically significant negative correlation between the mixed layer depth and the NP index.

Because the highest correlation was between the mixed layer and the NP index time series, both variables were plotted, revealing an inverse relationship between them (Figure 5). This negative and proportional relationship prevailed during most of the analysis period, with the exceptions of February 2002, when the $100 \mathrm{~m}$ mixed layer depth was registered and the relationship became very disproportional, and for March of 1996 and 2009, when the proportion of the negative relationship is unclear. Discarding these months the negative relationship becomes extremely high.

To analyze the anomalous conditions in the mixed layer depths described previously for 1996, 2002, and 2009, plots were made of the annual patterns for the NP, PNA, NOI, and SOI indices of these years (Figure 6). These plots show the contribution of the variability of each large-scale atmospheric related index that had an influence during the years of the anomalous mixed layer depths. In the case of the $100 \mathrm{~m}$ mixed layer depth in February 2002, the NP and SOI (Figure 6(a) and Figure 6(d)) values were lower than those in 2009, while the PNA and NOI (Figure 6(b) and Figure 6(c)) were higher than those in 2009. In the case of March 2009, the NP, NOI, and 




Figure 5. Time series of the mixed layer depth of La Paz Bay (solid line) and the corresponding NP index data (dashed line) from 1994 to 2009 (shadowareas denote unclear relationships).

Table 2. The mixed layer depth of La Paz Bay and the four North Pacific climate indices related to pressure variations from 1994 to 2009 with their Spearman correlations. P < 0.005, bolded numbers have a significant correlation.

\begin{tabular}{|c|c|c|c|c|c|}
\hline Samples & MLD & NP & PNA & NOI & SOI \\
\hline March 1994 & 40 & 1012.37 & 0.23 & -1.00 & -1.10 \\
\hline October 1995 & 35 & 1012.92 & 0.11 & 1.31 & 0.00 \\
\hline February 1996 & 35 & 1007.99 & -0.70 & -3.87 & 0.40 \\
\hline March 1996 & 0 & 1010.94 & -0.75 & -1.12 & 1.90 \\
\hline July 1996 & 9 & 1018.22 & 0.18 & 0.02 & 1.10 \\
\hline August 1996 & 0 & 1018.09 & -0.93 & 0.94 & 1.20 \\
\hline March 1997 & 40 & 1014.99 & -1.56 & 2.00 & -0.70 \\
\hline July 1997 & 20 & 1015.95 & 0.10 & -0.97 & -1.20 \\
\hline March 1998 & 50 & 1008.11 & 0.69 & -3.58 & -4.00 \\
\hline August 1998 & 0 & 1018.76 & -0.60 & 1.58 & 1.90 \\
\hline November 1999 & 50 & 1011.32 & 0.45 & -2.03 & 1.70 \\
\hline May 2001 & 14 & 1015.52 & -0.01 & -0.61 & -0.80 \\
\hline July 2001 & 5 & 1017.41 & -0.36 & 0.53 & -0.30 \\
\hline October 2001 & 30 & 1013.92 & -0.08 & 0.73 & -0.10 \\
\hline February 2002 & 100 & 1010.13 & -0.11 & 2.94 & 1.80 \\
\hline October 2004 & 30 & 1012.55 & -1.37 & -2.11 & -0.10 \\
\hline February 2005 & 40 & 1008.07 & -0.11 & -5.40 & -5.20 \\
\hline August 2006 & 10 & 1018.12 & -1.45 & -0.47 & -1.70 \\
\hline March 2007 & 20 & 1012.74 & -0.12 & 5.11 & 0.30 \\
\hline February 2008 & 22 & 1005.85 & 0.37 & 5.69 & 4.40 \\
\hline May 2008 & 15 & 1014.14 & 1.25 & 0.57 & -0.10 \\
\hline November 2008 & 35 & 1010.81 & 1.05 & 2.52 & 2.20 \\
\hline March 2009 & 0 & 1017.40 & -1.29 & 4.57 & 0.70 \\
\hline June 2009 & 10 & 1013.16 & 0.48 & -2.38 & 0.20 \\
\hline September 2009 & 0 & 1013.60 & 1.03 & 1.42 & 0.50 \\
\hline December 2009 & 50 & 1004.34 & 0.04 & -3.44 & -1.20 \\
\hline \multicolumn{2}{|c|}{ MLD Spearman $r_{s}=$} & -0.69 & 0.22 & -0.27 & -0.30 \\
\hline
\end{tabular}






Figure 6. Annual patterns for the climate indices in 1996, 2002, and 2009. (a) NP, (b) PNA, (c) NOI, and (d) SOI.

SOI were higher than in 2002 (Figure 6(a), Figure 6(c) and Figure 6(d)). The differences among the indices for these winter months and the correlations shown in Table 2 demonstrated that, not only does the NP phenomenon influence the mixed layer depth, but other atmospheric phenomena such as the PNA, NOI, and SOI do as well. In the particular case of 1996, different patterns registered throughout the year from those in 2002 and 2009, but in March, the PNA and SOI (Figure 6(b) and Figure 6(d)) were higher than those of 2002 and 2009.

\section{Discussion}

The annual variability of the La Paz Bay sea surface temperature showed that, although the bay is a semi-enclosed body of water, it has interannual variability and abrupt changes, such as occurred during the 2007 and 2009 years. This indicates La Paz Bay is highly dynamic and influenced by the North Pacific, which agrees with reports by [24] [41] [42] [45] [48], who described the seasonal changes of this bay and emphasized the influence of the ocean-atmospheric processes that determine its hydrographic conditions.

The mean annual thermal cycle occurs in two phases (warm and cold) with their respective transition periods having similar temperatures. This differs somewhat from the findings of [41] [42] [48], who consider the bay's hydrographic variability based on four seasons. The differences in the annual thermal cycle between 2007 and 2009 showed that the changes in the temperature of La Paz Bay occurred not only during the El Niño events, when the warm waters from the tropical regions influence the marine environment, but also during La Niña, when the changes in La Paz Bay also occurred alongside decreases in the temperature during the warm phase of the annual cycle. This contrasts with reports by [41] [42] [48] [51]-[53], who only focused their research efforts on the temperature increases in La Paz Bay during the El Niño events.

The anomalous surface temperature variations of La Paz Bay showed a high correlation among the ENSO indices, corroborating that the thermal fluctuations of the bay are caused by both phases of this phenomenon (El Niño/La Niña), primarily during the warm period of the annual thermal cycle of the bay through the entrance of surface waters from the tropical Pacific. This coincides with observations by [24] [41] [42] [45] [48], who registered tropical waters during both the warm and cold periods of the La Paz Bay annual cycle. However, other studies exist showing that the La Niña effects are also reflected in sea surface temperature decreases in the Gulf of California, such as those by [27] [28]. Based on the sea surface temperature anomalies obtained from satellite records, they showed that during El Niño/La Niña events, the monthly mean temperatures of the Gulf of California vary by up to $3^{\circ} \mathrm{C}$ from the normal conditions.

The variability of the mixed layer depth showed a high dependence on the wind conditions during the cold 
phase of the annual thermal cycle of the bay. [41] [45] showed that when the temperature decreases during the cold phase of the annual thermal cycle of the bay, the north winds velocities gradually rise, thereby increasing the mixed layer depth. Furthermore, [54] mentioned that the wind patterns in the Gulf of California correspond to a large-scale annual cycle of the Northeast Pacific. This was confirmed with the negative correlation obtained between the variability of the mixed layer depth and the NP index, showing that the wind patterns that regulate the depth's dimensions are determined by the atmospheric pressure variability of the Northeast Pacific.

Although the NP fluctuations are the primary factor generating the mixed layer variations, other phenomena must also be taken into consideration, as their indices were not significantly correlated. Such was the case in 1996, 2002, and 2009 when the anomalous mixed layer depths were registered. These were caused by the pressure variations of two or more of the atmospheric phenomena we analyzed that resulted in the changes of the wind magnitude and direction. [40] attempted to relate the large-scale phenomena to the variability of the mixed layer depth at the tropical boundary of the California Current by using CTD observations from 1997-2007. They affirmed that the seasonal and interannual variability of the mixed layer depth was correlated with offshore Ekman transport and that the abrupt mixed layer depth change that occurred between January 1998 and January 2000 was associated with a strong El Niño-La Niña shift.

\section{Acknowledgements}

We thank the Instituto Politécnico Nacional (IPN), Consejo Nacional de Ciencia y Tecnología (CONACYT), and Comisión de Operación y Fomento de Actividades Académicas del IPN (COFAA) for financial help and scholarships, in addition to the Secretaría de Investigación y Posgrado-Becas de Estímulo Institucional de Formación de Investigadores (SIP-BEIFI) and Becas de Estímulo al Desempeño de los Investigadores (SIP-EDI). We also thank American Manuscript Editors for editing this manuscript.

\section{References}

[1] Schwing, F.B., Murphree, T. and Green, P.M. (2002) The Northern Oscillation Index (NOI): A New Climate Index for the Northeast Pacific. Progress in Oceanography, 53, 115-139. http://dx.doi.org/10.1016/S0079-6611(02)00027-7

[2] Parrish, R.H., Schwing, F.B. and Mendelssohn, R. (2000) Mid-Latitude Wind Stress: The Energy Source for Climate Shifts in the North Pacific Ocean. Fisheries Oceanography, 9, 224-238. http://dx.doi.org/10.1046/j.1365-2419.2000.00136.x

[3] Wooster, W.S. and Hollowed, A.B. (1995) Decadal-Scale Variations in the Eastern Subarctic Pacific, 1: Winter Ocean Conditions. Canadian Special Publication of Fisheries and Aquatic Sciences, 121, 81-85.

[4] Bograd, S.J., Chereskin, T.K. and Roemmich, D. (2001) Transport of Mass, Heat, Salt, and Nutrients in the Southern California Current System: Annual Cycle and Interannual Variability. Journal of Geophysical Research, 106, 92559275. http://dx.doi.org/10.1029/1999JC000165

[5] Bernal, P.A. and Chelton, D.B. (1984) Variabilidad biológica de baja frecuencia y gran escala en la Corriente de California, 1949-1978 (Low Frequency and Large-Scale Biological Variability in the California Current, 1949-1978). In: Csirke, J. and Sharp, G.D., Eds., Reports of the Expert Consultation to Examine Changes in Abundance and Species Composition of Neritic Fish Resources. San José, Costa Rica, 18-29. A Preparatory Meeting for the FAO World Conference on Fisheries Management and Development. FAO Fisheries Report, 1, 102 p.

[6] Schwing, F.B., Murphree, T., deWitt, L. and Green, P.M. (2002) The Evolution of Oceanic and Atmospheric Anomalies in the Northeast Pacific during the El Nino and La Nina Events of 1995-2001. Progress in Oceanography, 54, 459-491. http://dx.doi.org/10.1016/S0079-6611(02)00064-2

[7] Deser, C., Alexander, M.A. and Timlin, M.S. (1999) Evidence for a Wind-Driven Intensification of the Kuroshio Current Extension from the 1970s to the 1980s. Journal of Climate, 12, 1697-1706. http://dx.doi.org/10.1175/1520-0442(1999)012<1697:EFAWDI>2.0.CO;2

[8] Barlow, M., Nigam, S. and Berbery, E.H. (2001) ENSO, Pacific Decadal Variability, and US Summertime Precipitation, Drought, and Stream Flow. Journal of Climate, 14, 2105-2128. http://dx.doi.org/10.1175/1520-0442(2001)014<2105:EPDVAU>2.0.CO;2

[9] Herrera-Cervantes, H., Lluch-Cota, D.B., Lluch-Cota, S.E. and Gutiérrez de Velasco, G. (2007) The ENSO Signature in Sea-Surface Temperature in the Gulf of California. Journal of Marine Research, 65, 589-605. http://dx.doi.org/10.1357/002224007783649529

[10] Chiew, F.H. and McMahon, T.A. (2002) Global ENSO-Streamflow Teleconnection, Streamflow Forecasting and Interannual Variability. Hydrological Sciences Journal, 47, 505-522. http://dx.doi.org/10.1080/02626660209492950 
[11] Trenberth, K.E. (1997) The Definition of El Niño. Bulletin of the American Meteorological Society, 78, $2771-2777$. http://dx.doi.org/10.1175/1520-0477(1997)078<2771:TDOENO>2.0.CO;2

[12] Mantua, N.J., Hare, S.R., Zhang, Y., Wallace, J.M. and Francis, R.C. (1997) A Pacific Interdecadal Climate Oscillation with Impacts on Salmon Production. Bulletin of the American Meteorological Society, 78, 1069-1079. http://dx.doi.org/10.1175/1520-0477(1997)078<1069:APICOW>2.0.CO;2

[13] Mantua, N.J. and Hare, S.R. (2002) The Pacific Decadal Oscillation. Journal of Oceanography, 58, 35-44. http://dx.doi.org/10.1023/A:1015820616384

[14] Mantua, N.J. (1999) The Pacific Decadal Oscillation and Climate Forecasting for North America. Joint Institute for the Study of the Atmosphere and Oceans, University of Washington, Seattle. http://www.atmos.washington.edu/ mantua/REPORTS/PDO/PDO_cs.htm

[15] Piechota, T.C., Garbrecht, J.D. and Schneider, J.M. (2006) Climate Variability and Climate Change. In: Garbrecht, J.D. and Piechota, T.C., Eds., Climate Variations, Climate Change, and Water Resources Engineering, ASCE, Reston, VA, $1-18$.

[16] Wallace, J.M. and Gutzler, D.S. (1981) Teleconnections in the Geopotential Height Field during the Northern Hemisphere Winter. Monthly Weather Review, 109, 784-812. http://dx.doi.org/10.1175/1520-0493(1981)109<0784:TITGHF>2.0.CO;2

[17] Wallace, J.M. (2000) North Atlantic Oscillation/Annular Mode: Two Paradigms-One Phenomenon. Quarterly Journal of the Royal Meteorological Society, 126, 791-805. http://dx.doi.org/10.1256/smsqj.56401

[18] Blackmon, M.L., Lee, Y.-H. and Wallace, J. (1984) Horizontal Structure of $500 \mathrm{mb}$ Height Fluctuations with Long, Intermediate and Short Time Scales. Journal of the Atmospheric Sciences, 41, 961-979. http://dx.doi.org/10.1175/1520-0469(1984)041<0961:HSOMHF>2.0.CO;2

[19] Blackmon, M.L., Lee, Y.-H., Wallace, J. and Hsu, H.-H. (1984) Time Variation of 500 mb Height Fluctuations with Long, Intermediate and Short Time Scales as Deduced from Lag-Correlation Statistics. Journal of the Atmospheric Sciences, 41, 981-991. http://dx.doi.org/10.1175/1520-0469(1984)041<0981:TVOMHF>2.0.CO;2

[20] Trenberth, K.E., Branstator, G.W., Karoly, D., Kumar, A., Lau, N. and Ropelewski, C. (1998) Progress during TOGA in Understanding and Modeling Global Teleconnections Associated with Tropical Sea Surface Temperature. Journal of Geophysical Research, 103, 14291-14324. http://dx.doi.org/10.1029/97JC01444

[21] Straus, D.M. and Shukla, J. (2002) Does ENSO Force the PNA? Journal of Climate, 15, 2340-2358. http://dx.doi.org/10.1175/1520-0442(2002)015<2340:DEFTP >2.0.CO;2

[22] Lin, J.L., Zhang, M.H. and Mapes, B.E. (2005) Zonal Momentum Budget of the Madden-Julian Oscillation: The Source and Strength of Equivalent Linear Damping. Journal of the Atmospheric Sciences, 62, 2172-2188. http://dx.doi.org/10.1175/JAS3471.1

[23] Trenberth, K.E. and Hurrell, J.W. (1994) Decadal Atmospheric-Ocean Variations in the Pacific. Climate Dynamics, 9, 303-319. http://dx.doi.org/10.1007/BF00204745

[24] Lavín, M.F., Beier, E. and Badan, A. (1997) Estructura hidrográfica y circulación del Golfo de California: Escalas estacional e interanual. In: Lavín, M.F., Ed., Contribuciones a la Oceanografía Física en México, Unión Geofísica Mexicana, Monografía No. 3, 141-171.

[25] Makarov, V.G. and Jiménez-Illescas, A.R. (2003) Barotropic Background Currents in the Gulf of California. Ciencias Marinas, 29, 141-153.

[26] Marinone, S.G. (2003) A Three Dimensional Model of the Mean and Seasonal Circulation of the Gulf of California. Journal of Geophysical Research, 108, 3325. http://dx.doi.org/10.1029/2002JC001720

[27] Soto-Mardones, L., Marinone, S.G. and Parés-Sierra, A. (1999) Time and Spatial Variability of Sea Surface Temperature in the Gulf of California. Ciencias Marinas, 25, 1-30.

[28] Lavín, M.F., Palacios-Hernández, E. and Cabrera, C. (2003) Sea Surface Temperature Anomalies in the Gulf of California. Geofísica Internacional, 42, 363-375.

[29] Latif, M. and Barnett, T.P. (1995) Interactions of the Tropical Oceans. Journal of Climate, 8, 952-964. http://dx.doi.org/10.1175/1520-0442(1995)008<0952:IOTTO >2.0.CO;2

[30] Zhang, Y., Wallace, J.M. and Battisti, D.S. (1997) ENSO-Like Interdecadal Variability: 1900-93. Journal of Climate, 10, 1004-1020. http://dx.doi.org/10.1175/1520-0442(1997)010<1004:ELIV>2.0.CO;2

[31] Hare, S. and Mantua, N. (2000) Empirical Evidence for North Pacific Regime Shifts in 1977 and 1989. Progress in Oceanography, 47, 103-145. http://dx.doi.org/10.1016/S0079-6611(00)00033-1

[32] Martinez, E., Antoine, D., D’Ortenzio, F. and Gentili, B. (2009) Climate-Driven Basin-Scale Decadal Oscillations of Oceanic Phytoplankton. Science, 326, 1253-1256. http://dx.doi.org/10.1126/science.1177012

[33] Di Lorenzo, E., Schneider, N., Cobb, K.M., Chhak, K., Franks, P.J.S., Miller, A.J., McWilliams, J.C., Bograd, S.J., 
Arango, H., Curchister, E., Powell, T.M. and Rivere, P. (2008) North Pacific Gyre Oscillation Links Ocean Climate and Ecosystem Change. Geophysical Research Letters, 35, Article ID: L08607. http://dx.doi.org/10.1029/2007GL032838

[34] Horel, J.D. and Wallace, J.M. (1981) Planetary-Scale Atmospheric Phenomena Associated with the Southern Oscillation. Monthly Weather Review, 109, 2080-2092. http://dx.doi.org/10.1175/1520-0493(1981)109<2080:ARPCAO>2.0.CO;2

[35] Namias, J. and Cayan, D.R. (1981) Large-Scale Air-Sea Interactions and Short Period Climate Fluctuations. Science, 214, 869-876. http://dx.doi.org/10.1126/science.214.4523.869

[36] Wallace, J.M. and Jiang, Q. (1987) On the Observed Structure of the Interannual Variability of the Atmosphere-Ocean Climate System. In: Cattle, H., Ed., Atmospheric and Oceanic Variability, Royal Meteorological Society, Bracknell, 17-43.

[37] Hoskins, B.J. and Karoly, D.J. (1981) The Steady Linear Response of a Spherical Atmosphere to Thermal and Orographic Forcing. Journal of the Atmospheric Sciences, 38, 1179-1196. http://dx.doi.org/10.1175/1520-0469(1981)038<1179:TSLROA>2.0.CO;2

[38] Wallace, J.M., Smith, C. and Bretherton, C.S. (1992) Singular Value Decomposition of Wintertime Sea Surface Temperature and $500 \mathrm{mb}$ Height Anomalies. Journal of Climate, 5, 561-576. http://dx.doi.org/10.1175/1520-0442(1992)005<0561:SVDOWS>2.0.CO;2

[39] Limsakul, A., Saino, T., Midorikawa, T. and Goes, J.I. (2001) Temporal Variations in Lower Trophic Level Biological Environments in the Northwestern North Pacific Subtropical Gyre from 1950 to 1997. Progress in Oceanography, 49, 129-149. http://dx.doi.org/10.1016/S0079-6611(01)00019-2

[40] Jerónimo, G. and Gómez-Valdés, J. (2010) Mixed Layer Depth Variability in the Tropical Boundary of the California Current, 1997-2007. Journal of Geophysical Research, 115, Article ID: C05014. http://dx.doi.org/10.1029/2009JC005457

[41] Obeso-Nieblas, M., Shirasago-Germán, B., Gaviño-Rodríguez, J.H., Pérez-Lezama, E.L., Obeso-Huerta, H. and JiménezIllescas, A.R. (2008) Variabilidad hidrográfica en Bahía de La Paz, Golfo de California, México (1995-2005). Revista de Biología Marina y Oceanografía, 43, 559-567. http://dx.doi.org/10.4067/S0718-19572008000300015

[42] Obeso-Nieblas, M. (2003) Variabilidad espaciotemporal de las condiciones oceanográficas de la Bahía de La Paz, BCS, México. Ph.D. Dissertation, Centro Interdisciplinario de Ciencias Marinas, Instituto Politécnico Nacional, Mexico City.

[43] Guevara-Guillén, C. (2011) Hidrografía en Bahía de La Paz y zona oceánica adyacente. Masters Dissertation, Centro Interdisciplinario de Ciencias Marinas, Instituto Politécnico Nacional, Mexico City.

[44] Cruz Orozco, R., Martínez-Noriega, C. and Mendoza-Maravillas, A. (1996) Batimetría y sedimentos en la Bahía de La Paz. Oceánides, 7, 21-27.

[45] Salinas-González, F., Zaytsev, O. and Makarov, V.G. (2003) Formación de estructura termohalina del agua en la Bahía de La Paz de verano a otoño. Ciencias Marinas, 29, 51-65.

[46] Sánchez-Velasco, L., Beier, E., Avalos-Garcia, C. and Lavín, M.F. (2006) Larval Fish Assemblages and Geostrophic Circulation in Bahia de La Paz and the Surrounding Southwestern Region of the Gulf of California. Journal of Plankton Research, 28, 1-18. http://dx.doi.org/10.1093/plankt/fbl040

[47] Zaytsev, O., Rabinovich, A.B., Thomson, R.E. and Silverberg, N. (2010) Intense Diurnal Surface Currents in the Bay of La Paz, Mexico. Continental Shelf Research, 30, 608-619. http://dx.doi.org/10.1016/j.csr.2009.05.003

[48] Obeso-Nieblas, M., Shirasago-Germán, B., Sánchez-Velasco, L. and Gaviño-Rodríguez, J.H. (2004) Hydrographic Variability in Bahía de La Paz, BCS, México, during the 1997-1998 El Niño. Deep Sea Research Part II, 51, 689-710. http://dx.doi.org/10.1016/j.dsr2.2004.05.005

[49] Kahru, M. (2014) Windows Image Manager, WIM Software (Ver. 7.05) and User’s Manual, 125 p. http://www.wimsoft.com/

[50] Climate Prediction Center Internet Team (2005) Oceanic Niño Index (ONI), Multivariate ENSO Index (MEI), Bivariate ENSO Timeseries (BEST), Southern Oscillation Index (SOI), Northern Oscillation Index (NOI), Pacific Decadal Oscillation (PDO), Pacific North American index (PNA) and North Pacific Pattern Index (NP) (Online). NOAA/National Weather Service, National Centers for Environmental Prediction, Climate Prediction Center. http://www.esrl.noaa.gov/psd/data/climateindices/list/

[51] Castro, R., Mascareñas, A.S., Durazo, R. and Collins, C.A. (2000) Seasonal Variation of the Temperature and Salinity at the Entrance to the Gulf of California, México. Ciencias Marinas, 26, 561-583.

[52] Sánchez-Velasco, L., Valdéz-Holguín, J.E., Shirasago-Germán, B., Cisneros-Mata, M.A. and Zárate, A. (2002) Changes in the Spawning Environment of Sardinops caeruleus in the Gulf of California during El Niño 1997-1998. Estuarine Coastal and Shelf Science, 54, 207-217. http://dx.doi.org/10.1006/ecss.2001.0840 
[53] Pacheco-Ruíz, I., Becerril-Bobadilla, F., Zertuche-González, J.A., Barragán, A.C., Gálvez-Telles, A. and Blanco-Betancourt, R. (2003) Effects of El Niño on Beds of Ulva lactuca along the Northwest Coast of the Gulf of California, Mexico. Geofísica Internacional, 42, 447-454.

[54] Douglas, M.W., Maddox, R.A., Howard, K. and Reyes, S. (1993) The Mexican Monsoon. Journal of Climate, 6, 16651678. http://dx.doi.org/10.1175/1520-0442(1993)006<1665:TMM>2.0.CO;2 
Scientific Research Publishing (SCIRP) is one of the largest Open Access journal publishers. It is currently publishing more than 200 open access, online, peer-reviewed journals covering a wide range of academic disciplines. SCIRP serves the worldwide academic communities and contributes to the progress and application of science with its publication.

Other selected journals from SCIRP are listed as below. Submit your manuscript to us via either submit@scirp.org or Online Submission Portal.
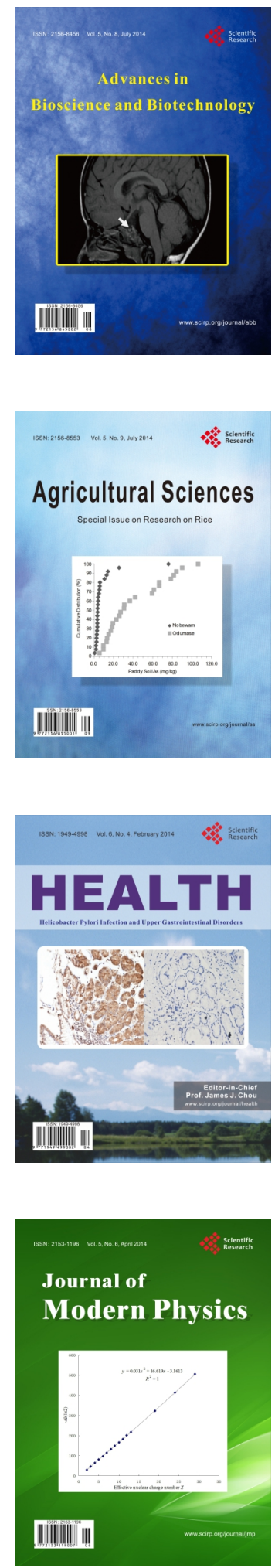
